\title{
Critical evaluation of normotensive rats as models for hypercholesterolaemia-induced atherosclerosis"
}

\author{
P.M. Pisulewski ${ }^{1,3}$, R.B. Kostogrys ${ }^{1}$, B. Lorkowska ${ }^{2}$, M. Bartuś ${ }^{2}$ \\ and S. Chłopicki
}

\author{
${ }^{1}$ Department of Human Nutrition, Faculty of Food Technology, \\ Agricultural University of Kraków \\ al. 29 Listopada 46, 31-425 Kraków, Poland \\ ${ }^{2}$ Department of Experimental Pharmacology, Chair of Pharmacology, \\ Jagiellonian University Medical College \\ Grzegórzecka 16, 31-531 Kraków, Poland
}

(Received 30 November 2004; accepted 18 March 2005)

\begin{abstract}
In view of recent findings describing atherosclerosis as an inflammatory disease, the objective of the present study was to re-evaluate critically the potential of normotensive Wistar rats to represent a model for diet-induced hypercholesterolaemia and the hypercholesterolaemia induced atherosclerosis. Fourty five-week-old male rats were randomly allocated into two groups $(n=20)$ and fed two different diets for 12 weeks: I - control AIN-93G diet and II - hypercholesterolaemic (high-cholesterol, high-cholate) AIN-93G diet, containing cholesterol (1 g/100 g) and cholate $(0.5 \mathrm{~g} / 100 \mathrm{~g})$. Serum lipid profile, plasma inflammatory markers and endothelial functions were examined after $0,4,8$ and 12 weeks. In addition, the atherosclerotic lesions formation in the aorta was evaluated after 12 weeks. In contrast to the control animals, the rats fed the hypercholesterolaemic diet had an elevated concentration of total serum cholesterol (2.05 vs $7.97 \mathrm{mmol} / \mathrm{L})$ and LDLcholesterol ( $0.63 \mathrm{vs} 6.80 \mathrm{mmol} / \mathrm{L})$. At the same time, the hypercholesterolaemic diet only slightly decreased serum HDL-cholesterol and had no effect on triglicerides. The hypercholesterolaemic diet, compared with the control diet, increased mildly plasma proinflammatory interleukin-6 concentrations $(2.68$ vs $4.85 \mathrm{pg} / \mathrm{ml})$ whereas plasma C-reactive protein concentrations were below the detection limit $(<0.01 \mathrm{pg} / \mathrm{ml})$. The relaxation concentration curves to acetylcholine (to test endothelium-dependent relaxation) were not impaired in rats fed the hypercholesterolaemic diet. Also, the hypercholesterolaemic diet did not induce atherosclerotic lesion formation in the aortas of rats. In conclusion, diet-induced hypercholesterolaemia in normotensive rats induces only mild inflammatory process of the endothelium but it does not affect endothelial functions.
\end{abstract}

\footnotetext{
*Supported by the State Committee for Scientific Research, Grant No. 3-P06T-029-24 and 3P05A 003 25, and by Professorial Grant from Foundation for Polish Science (SC)

${ }^{3}$ Corresponding author: e-mail: rrpisule@cyf-kr.edu.pl
} 
Consequently, diet-induced hypercholesterolaemia does not lead to progression of atherosclerosis in rats thus invalidating the use of these animals as models for studies on hypercholesterolaemiainduced atherosclerosis.

KEY WORDS: normotensive rats, hypercholesterolaemia, endothelial functions, atherosclerosis

\section{INTRODUCTION}

A laboratory rat is generally considered an atherosclerosis-resistant species (Moghadasian, 2002). Indeed, even under conditions of extreme hypercholesterolaemia, rats do not develop atherosclerosis. The explanation of this phenomenon is still lacking. It might be due to apparent differences in the distribution of cholesterol in the lipoprotein fractions between rats and humans. Unlike humans, rats carry the majority of blood cholesterol (60-80\%) in high-density lipoproteins (HDL) and only $5-10 \%$ in atherogenic low-density lipoproteins (LDL) (Day et al., 1979; Moghadasian, 2002). Also, diminished activity of cholesteryl ester transfer protein (CETP), involved in the reverse transport of cholesterol, can play a role (Mangiapane and Salter, 1999).

At the same time, feeding rats with diets containing saturated fat, cholesterol and cholic acid or both, induced severe hypercholesterolaemia. In fact, the above diets induced marked increases in LDL-cholesterol concentrations in rats, thus producing a human-like serum lipid profile (e.g., Pisulewski et al., 2002; Vasconen et al., 2002). Consequently, cholesterol-fed rats were frequently used as models for human hypercholesterolaemia and atherosclerosis, to test hypocholesterolaemic (Morita et al., 1997) and antiatherogenic (Vasconen et al., 2002) properties of various food components. Interestingly, several of these components e.g., plant proteins (Morita et al., 1997; Chango et al., 1998; Madani et al., 1998; Macarulla et al., 2001), plant sterols (Vasconen et al., 2002), $\beta$-glucans (Bagger et al., 1996; Hecker et al., 1998; Friedrich and Piech, 2000; Wołoch and Pisulewski, 2003) and polyphenols (Troszyńska and Bałasińska, 2002), counteracted, at least in part, the diet-induced hypercholesterolaemia. Nevertheless, in most of these studies, no histological evidence of atherosclerosis was provided.

In contrast to the hypercholesterolaemic theory of athereosclerosis, elevated serum cholesterol concentrations are no longer accepted as prerequisite for the development of this disease in humans or experimental animals (Stehbens, 2001a,b). Moreover, cholesterol should be considered a metabolite reflecting liporotein metabolism and not a biomarker of disease, although in some individuals, it may indicate the progression of atherosclerosis (German et al., 2004). Instead, atherosclerosis has been defined as an inflammatory disease that begins with dysfunction of the vascular endothelium (Ross, 1999; Libby, 2000; Bonetti et al., 2003). Moreover, 
markers of inflammation, e.g., C-reactive protein (CRP) and proinflammatory cytokine interleukin-6 (IL-6), and markers of endothelial dysfunction, e.g., Eselectin, soluble intercellular adhesion molecule 1 (sICAM-1) and soluble vascular cell adhesion molecule 1 (sVCAM-1), are highly predictive of atherosclerosis risk (Pasceri et al., 2000; Ridker et al., 2000). CRP may mediate opsonization of LDL by macrophages, a critical step in the formation of fatty streaks in the endothelium and plaque formation. It may also help induce increased expression of SICAM-1 and sVCAM-1, facilitating the migration and tethering of cells to sites of injury in the endothelium (Suk et al., 2005). Interest has recently focused also on the heat shock proteins (HSPs) and their possible role in atherosclerosis. HSP may serve as a mediator of atherosclerosis (Lamb et al., 2002).

In view of the above findings, the aim of the present study was to reassess critically the potential of normotensive Wistar rats to represent a model for diet-induced hypercholesterolaemia and the hypercholesterolaemia-induced atherosclerosis. For that purpose normotensive Wistar rats were fed with a hypercholesterolaemic diet for 12 weeks. In the course of experiment 1 . serum lipid profile, 2. inflammatory responses, 3. endothelial functions, and 4. development of aortic atherosclerotic lesions, were evaluated.

\section{MATERIAL AND METHODS}

The experiments were conducted according to the Guidelines for Animal Care and Treatment of the European Community and were approved by the Local Animal Ethics Commission.

\section{Animals and feeding}

Growing five-week-old albino male rats $(\mathrm{n}=40)$, weighing initially $100-120$ $\mathrm{g}$ were obtained from the National Research Institute of Animal Production (Balice, Poland). The rats were housed individually in hanging stainless-steel, wire-bottomed cages, in an isolated room at controlled temperature and ambient humidity. Lights were maintained on a $12 \mathrm{~h}$ light-dark cycle. The animals were acclimated to these conditions for 1 week and given free access to water and the basal semipurified AIN-93G diet (Reeves et al., 1993). After the adaptation period, the rats were randomly divided into two equal groups $(\mathrm{n}=20)$ and fed two different diets for 12 weeks: 1 - control diet (basal AIN-93G diet) and 2 hypercholesterolaemic (high-cholesterol, high-cholate) diet (basal AIN-93G diet $+1 \mathrm{~g} / 100 \mathrm{~g}$ cholesterol $+0.5 \mathrm{~g} / 100 \mathrm{~g}$ cholic acid). The composition of both diets is shown in Table 1. 
TABLE 1

Composition of experimental diets based on AIN93G (Reeves et al., 1993) formulation, g/kg diet

\begin{tabular}{lcc}
\hline Ingredient & Control & Atherogenic \\
\hline Maize starch & 529.50 & 514.50 \\
Casein $(95 \% \mathrm{~N} \times 6.25)$ & 200.00 & 200.00 \\
Sucrose & 100.00 & 100.00 \\
Soyabean oil & 70.00 & 70.00 \\
Fibre $^{1}$ & 50.00 & 50.00 \\
Mineral mix $^{2}$ & 35.00 & 35.00 \\
Vitamin mix $^{3}$ & 10.00 & 10.00 \\
L-cystine $^{4}$ & 3.00 & 3.00 \\
Choline bitartrate $^{5}$ & 2.50 & 2.50 \\
Tert-butylhydroquinone $^{6}$ & 0.014 & 0.014 \\
Cholesterol $^{7}$ & - & 10.00 \\
Cholic acid $^{8}$ & - & 5.00 \\
\hline
\end{tabular}

${ }^{1}$ Alpha cellulose powder - Sigma (St. Louis, MO, USA); ${ }^{2}$ AIN-93G-MX (Reeves et al., 1993)

${ }^{3}$ AIN-93G-VX (Reeves et al., 1993); $4,5,6$ Sigma (St. Louis, MO, USA); ${ }^{7}$ Aldrich (Steinheim, Gemany); ${ }^{8}$ Fluka (Buchs, Switzerland)

\section{Determination of lipid profile and plasma inflammatory markers (IL-6, CRP)}

After $0,4,8$ and 12 weeks of feeding with the respective diets, four rats from each group were deprived of food overnight, anesthetized intraperitoneally with sodium thiopental (Biochemie, Vienna, Austria; $25 \mathrm{mg} / 100 \mathrm{~g}$ body mass) and killed by withdrawing blood from the heart. Blood samples $(n=2)$ were collected in test tubes and centrifuged ( $4000 \mathrm{~g}, 10 \mathrm{~min}$ ) to obtain serum. The serum samples were analysed using commercially available kits for: total cholesterol (OSR 6116), HDL-cholesterol (OSR 6156) and triacylglycerols (OSR 6133), respectively; each product from Olympus Diagnostica GmbH, Hamburg (Germany). The concentration of LDL-cholesterol was calculated according to the formula of Friedewald et al. (1972). Additional blood samples $(n=2)$ were collected in test tubes with sodium citrate as an anticoagulant and centrifuged $(4000 \mathrm{~g}, 10 \mathrm{~min})$ to obtain plasma. Plasma samples were immediately frozen $\left(-20^{\circ} \mathrm{C}\right)$ and stored for determination of pro-inflammatory intrerleukin-6 (IL-6) concentration and C-reactive protein (CRP) using DPC Immulite IL-6 assay kit and DPC Immulite CRP assay kit (Diagnostic Products Corporation, Los Angeles, USA), respectively.

\section{Assessment of vascular endothelial functions}

After $0,4,8$, and 12 weeks of feeding with the respective diets, three rats from each group were euthanized by intraperitoneal thiopental injection $(100 \mathrm{mg} / \mathrm{kg}$ body mass). Immediately after death, the aortas were rapidly dissected, washed 
out with ice-cold saline, and placed in Krebs-Hanseleit solution containing (mM): sodium chloride 118.0 , potassium chloride 4.7 , calcium chloride 2.52 , magnesium sulphate 1.64 , potassium phosphate monobasic 1.18 , sodium bicarbonate 24.88 , sodium bicarbonate 2.0 and glucose $10.0 ; \mathrm{pH} 7.4$. The solution was oxygenated with mixture of oxygen (95\%) and carbon dioxide (5\%). After careful removal of the surrounding adventitial tissue, the aortas were cut into rings approximately $3 \mathrm{~mm}$ in length. Six rings from each aorta were used for an experiment. Aortic rings were carefully mounted on 2 specimen holders and placed in a classic 5-ml organ bath chamber filled out with oxygenated Krebs-Hanseleit solution $\left(37^{\circ} \mathrm{C}\right)$. One holder was stationary while the other one was connected to an isometric force transducer (Biegastab K30 type 351; Hugo Sachs March-FR, Germany) coupled with a recorder (Graphtec WR3320, UK). All experiments were performed on aortic rings with endothelium. The aortic rings were incubated for $40 \mathrm{~min}$ to equilibrate. Next they were stretched in step-wised fashion to a final preload of $4.0 \mathrm{~g}$. During this time organ chamber was repeatedly washed. Maximal contraction was evoked by $\mathrm{KCl}$ (usually $60-120 \mathrm{mM}$ ), then a submaximal contraction (approximately $50-90 \%$ of maximal $\mathrm{KCl}$-induced contraction) was induced by an $\alpha_{1}$-adrenergic agonist-phenylephrine $\left(3 \times 10^{-8}-10^{-5} \mathrm{M}\right)$. Endothelial functions were assessed by cumulative concentration-dependent responses to an endothelium-dependent vasodilator-acetylcholine (0.1-10 $\mu \mathrm{M})$. Moreover, an endothelium-independent vasodilator-S-nitroso-N-acyl-penicillamine (SNAP: 0.1-1.0 $\mu \mathrm{M}$ ), was used to test smooth muscle cell functions. Then cumulative concentration-dependent curves for acetylcholine were repeated in presence of an inhibitor of nitric oxide synthesis - $N^{\mathrm{G}}$-nitro-L-arginine methyl ester (L-NAME; $300 \mu \mathrm{M}$ ). L-NAME was incubated for at least $15 \mathrm{~min}$ before eliciting responses to acetylcholine. Experiments on aortic rings derived from the control rats ( 3 rings per rat) and the rats fed with the high-cholesterol diet ( 3 rings per rat) were done simultaneously. Since there were no differences in relaxant response to acetylcholine of aortic rings, from the rats fed with the respective diets, for 4,8 and 12 weeks, only the latter data are presented. All relaxation results are expressed as a percentage of the maximal precontraction of phenyleprine-induced responses.

\section{Tissue preparation and histological examination of atherosclerosis}

The dissected proximal aortas were gently washed to remove blood and fixed immediately in $10 \%$ buffered formalin $(\mathrm{pH} 7.4)$ for about $24 \mathrm{~h}$ at room temperature. They were washed again for $2 \mathrm{~h}$, dehydrated through a graded ethanol series, placed in xylen ( 3 times for $15 \mathrm{~min}$ ), embedded in parafin $\left(58^{\circ} \mathrm{C}\right.$, $3 \mathrm{~h}$ ) and cast into blocks. Tissue samples were cut into approximately $5 \mu \mathrm{m}$ thick sections by microtome, placed on glass slides and stained by hematoxylin 
and eosin. Serial sections of the proximal aorta starting from the aortic root up to the bifurcation of carotid artery were examined. Light microscopic examination and photographic documentation were performed using a Zeiss microscope connected to a digital camera (Olympus).

\section{Statistical analysis}

Results are expressed as means \pm SEM. Where appropriate, the data were subjected to one-way analysis of variance generated by STATISTICA version 6.1 package (StatSoft, Inc., USA). The differences between treatment means were considered significant at $\mathrm{P}<0.05$ and $\mathrm{P}<0.01$.

\section{RESULTS}

Effect of hypercholesterolaemic diet on serum lipid profile and inflammatory markers. The hypercholesterolaemic (high-cholesterol, high-cholate) diet induced apparent changes in total serum cholesterol (TC) concentrations in rats, compared with the control diet (Figure 1A). In rats, fed with the control diet for 12 weeks, TC levels were stable, averaging $2.05 \mathrm{mmol} / \mathrm{L}$, whereas in rats fed with the hypercholesterolaemic diet, TC progressively increased, over the experimental period (0-12 weeks), from 2.21 to $7.97 \mathrm{mmol} / \mathrm{L}$, respectively. These changes resulted mainly from increases in LDL-cholesterol (Figure 1B). Rats fed the control diet did not show any apparent changes in LDL-cholesterol at $0,4,8$ and 12 weeks (averaging $0.63 \mathrm{mmol} / \mathrm{L}$ ), whereas those fed the hypercholesterolaemic diet had progressively (up to ten-fold) elevated LDLcholesterol $(0.70,3.89,4.29$ and $6.80 \mathrm{mmol} / \mathrm{L}$, respectively). At the same time, the hypercholesterolaemic diet only slightly decreased serum HDL-cholesterol and had no significant effect on serum triglyceride levels (Figures 1C and 1D). In rats fed the control diet, plasma interleukin-6 (IL-6) concentrations were fairly stable $(2.68 \mathrm{pg} / \mathrm{ml}$, on average $)$ over the entire experimental period (Figure 2). Conversely, IL-6 levels were slightly increased in rats fed the hypercholesterolaemic diet: from 3.59 to $4.05,6.30$ and $4.85 \mathrm{pg} / \mathrm{ml}$, at 0,4 , 8 and 12 weeks, respectively. In contrast plasma CRP levels were below the detection limit $(<0.01 \mathrm{pg} / \mathrm{ml})$ in the respective groups of rats. 
A

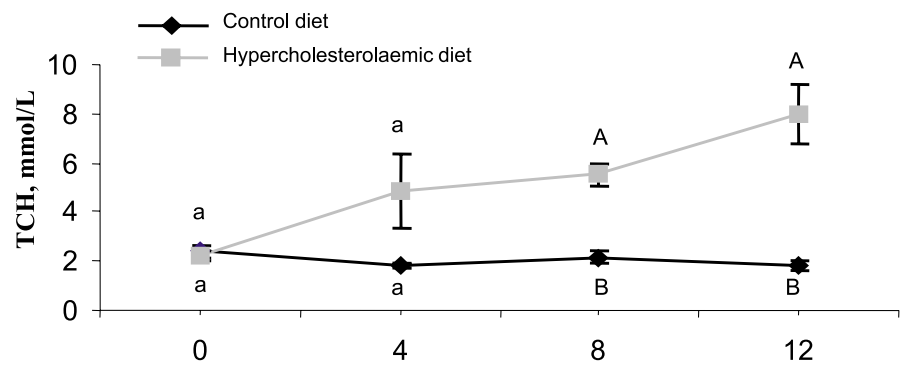

B

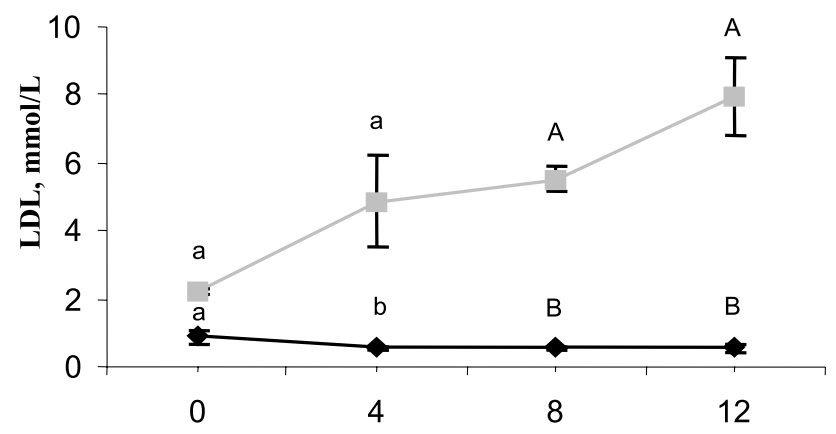

C

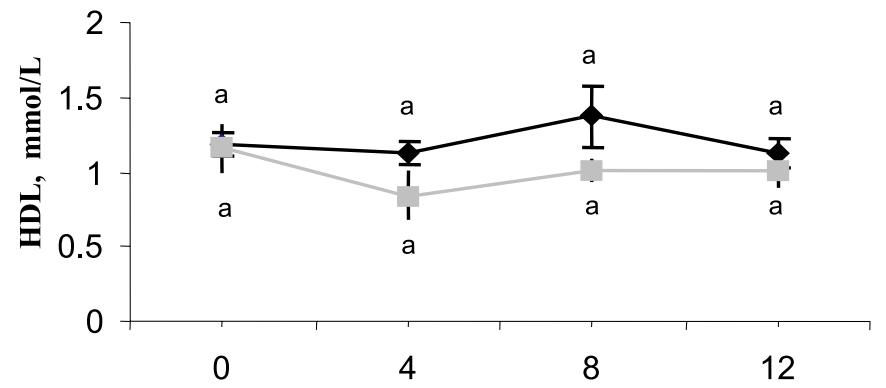

D

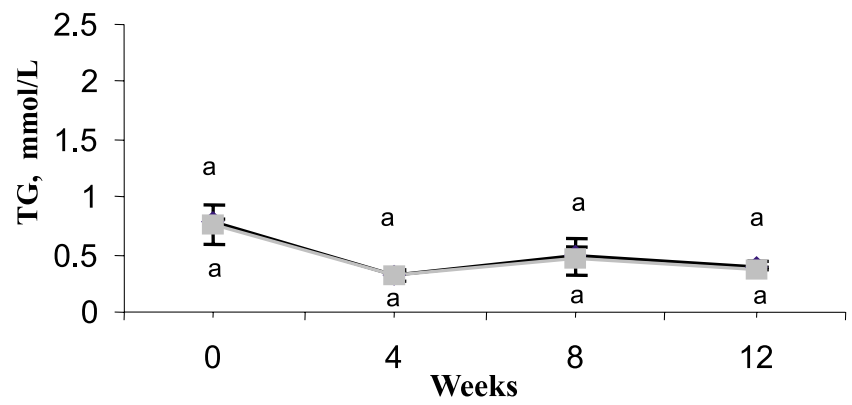

Figure 1. Serum levels of total cholesterol (A), LDL-cholesterol (B), HDL-cholesterol (C) and triglycerides (D) in Wistar rats fed the control and the hypercholesterolaemic diet for $0,4,8$ and 12 weeks. Values are means \pm SEM $(n=4)$. Means for a week without a common letter differ significantly (a,b: $\mathrm{P}<0.05$; $\mathrm{A}, \mathrm{B}: \mathrm{P}<0.01)$ 


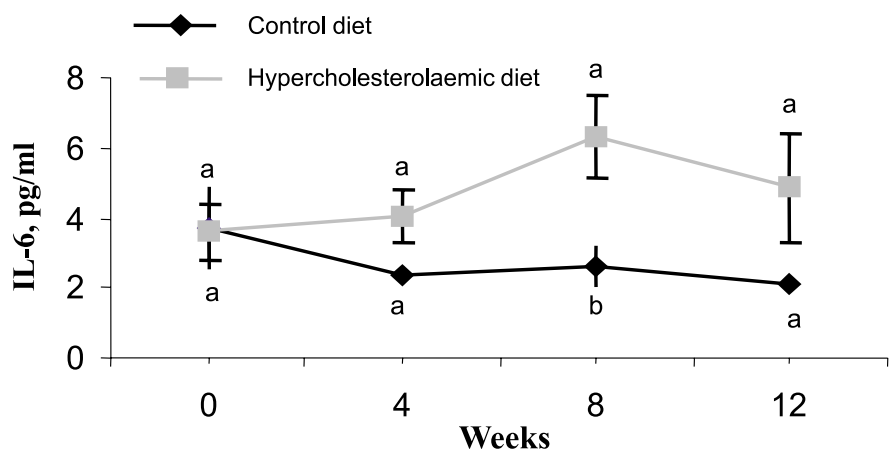

Figure 2. Plasma interleukin-6 (IL-6) concentrations in Wistar rats fed the control and the hypercholesterolaemic diet for $0,4,8$ and 12 weeks. Values are means \pm SEM $(n=4)$. Means for a week without a common letter differ significantly (a,b: $\mathrm{P}<0.05$; $\mathrm{A}, \mathrm{B}: \mathrm{P}<0.01)$

Effects of hypercholesterolaemic diet on endothelium-dependent responses. The endothelium-dependent relaxation responses of aortic rings to acetylcholine were not impaired in rats fed with the hypercholesterolaemic diet for 12 weeks, as compared with those fed with the control diet (Figure 3). In presence of L-NAME, an inhibitor of nitric oxide synthesis, acetylcholine-induced relaxation responses were equally abolished, irrespective of the dietary treatment. In addition, endothelium-independent relaxation responses to SNAP (as a nitric oxide donor) were similar in rats fed the hypercholesterolaemic and the control diet (for $1.0 \mu \mathrm{M}$ SNAP: $72.5 \pm 15.9 \%$ vs $91.2 \pm 8.12 \%$, respectively).

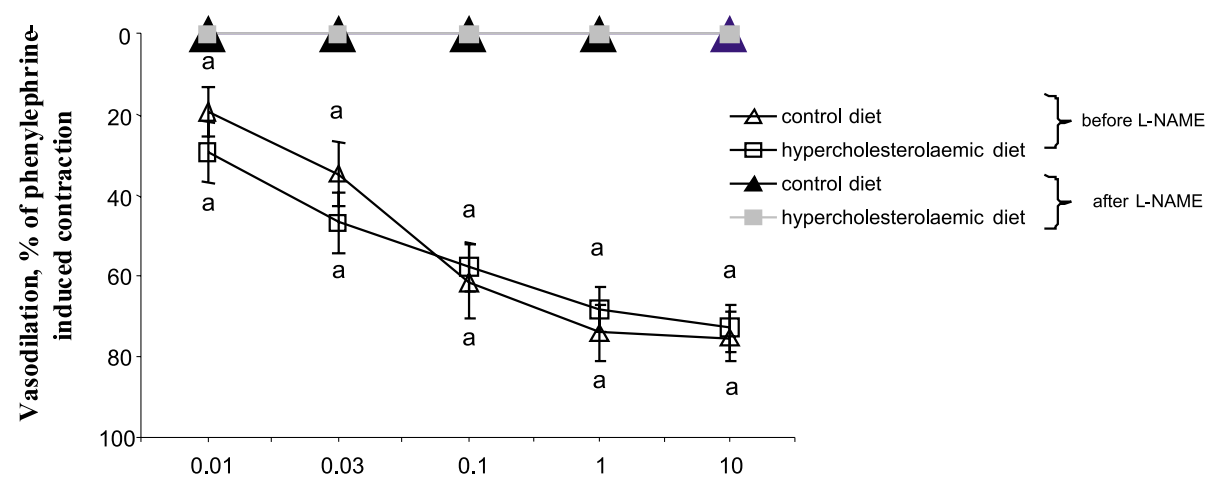

Acetylcholine, mM

Figure 3. Cumulative relaxation responses to acetylcholine (in the presence and in the absence of L-NAME), expressed as a percentage of phenylephrine-induced precontraction of isolated endothelium-intact arterial rings, from rats fed the control and the hypercholesterolaemic diet for 12 weeks. Values are means \pm SEM $(n=3)$. Means for an acetylcholine concentration without a common letter differ significantly 
Effects of hypercholesterolaemic diet on development of atherosclerotic lesions. The proximal aortas from rats, fed for 12-weeks with the hypercholesterolaemic diet, did not show any pathological changes indicative of atherosclerotic plaque formation (Figure 4). Endothelium, intima and adventitia were unchanged.

A

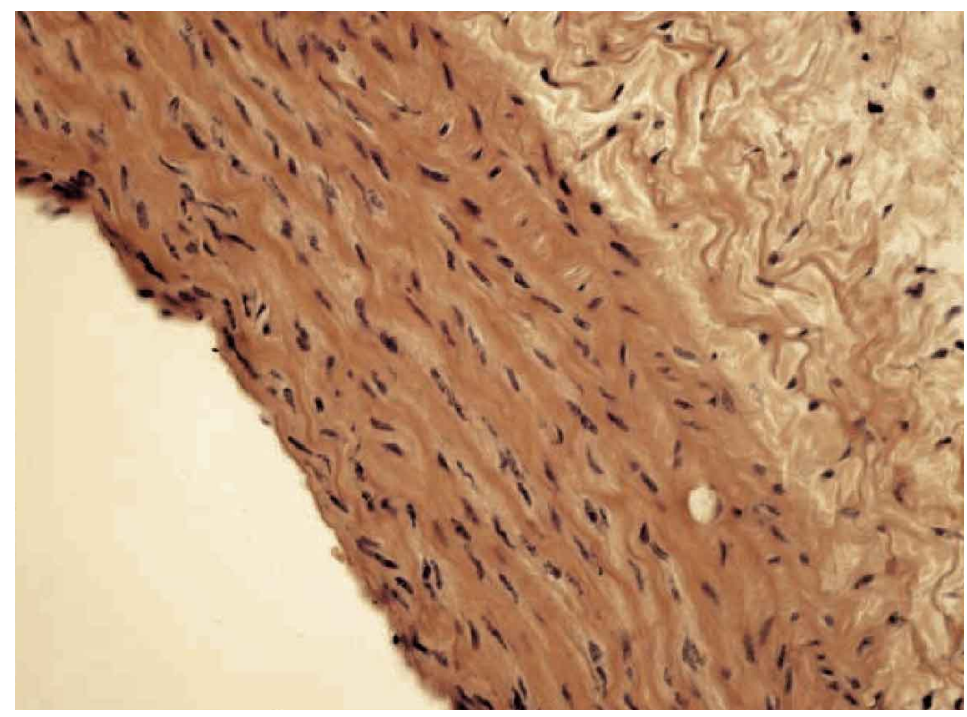

B

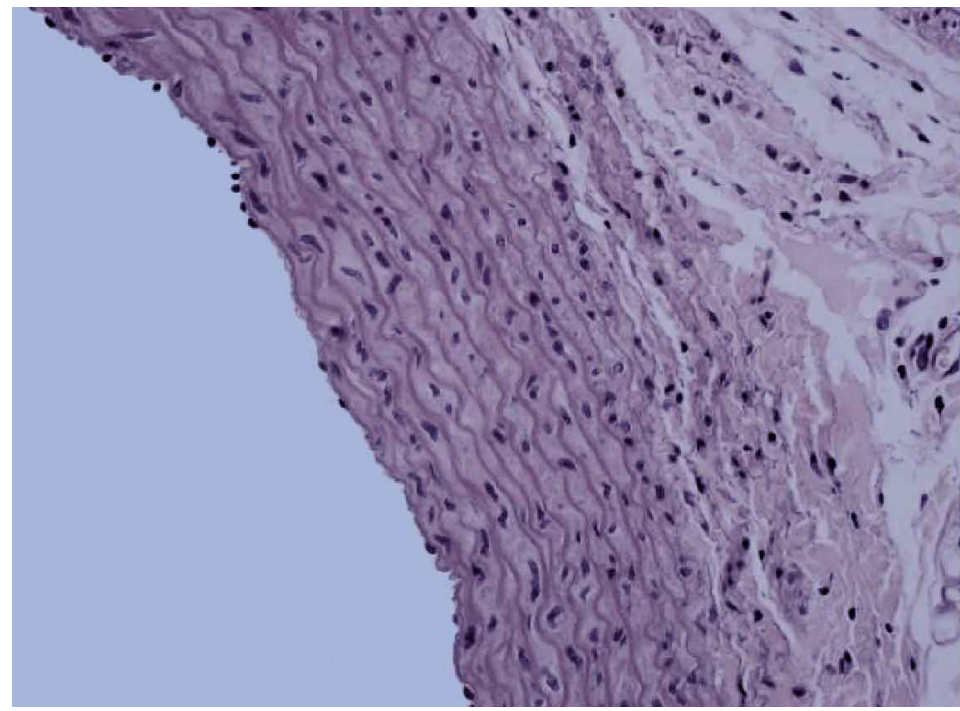

Figure 4. Light microscopy photographs of cross sections of the aortas, stained with hematoxylin and eosin, from rats fed the control (A) and the hypercholesterolaemic (B) diet for 12 weeks 


\section{DISCUSSION}

The elevated serum total- and LDL-cholesterol concentrations in rats fed hypercholesterolaemic (high-cholesterol, high-cholate) diets are the common feature of similar experiments. For example, severe hypercholesterolaemia was induced in rats (Pisulewski et al., 2002; Vasconen et al., 2002) and more recently in atherosclerosis susceptible $\mathrm{F}_{1} \mathrm{~B}$ hybrid hamsters (McAteer et al., 2003; Ntianos et al., 2003) fed hypercholesterolaemic diets. However, it should be stressed that hypercholesterolaemia in rats may be induced only by high-fat and highcholesterol diets containing cholic acid. As indicated by Madani et al. (1998) and Moghadasian (2002), cholic acid concomitantly increases cholesterol absorption and decreases cholesterol 7- $\alpha$-hydrolase activity, involved in cholesterol conversion to bile acids, thus resulting in decreased cholesterol excretion and elevated serum cholesterol concentrations.

Despite the above difference between rats and other rodent species rats have been frequently used as models for human-like hypercholesterolaemia and assumed atherosclerosis development. At the same time it is known that rats are generally hypo-responsive do dietary cholesterol and are considered atherosclerosis-resistant species (Madani et al., 1998; Moghadasian, 2002). Here we look at this issue again in the light of the current understanding of pathogenesis of atherosclerosis. Today atherosclerosis is understood as a chronic inflammatory disease of the vascular wall (Ross, 1999; Lusis, 2000; Blake and Ridker, 2001; Libby et al., 2002). Importantly, endothelial dysfunction and low-grade systemic inflammation are crucially involved in atherosclerosis development and their assessment offer diagnostic and prognostic value in patients with atherosclerosis. In particular, NO-dependent vascular function and markers of systemic inflammation are increasingly used to define patients at risk of cardiovascular events (Blake and Ridker, 2001; Bonetti et al., 2003). That is why, we analyse here the impact of hypercholesterolaemia in rats on NO-dependent vascular function and systemic inflammatory response. Importantly, it was recently suggested (Lopez-Garcia et al., 2004), that major dietary patterns in humans are related to plasma concentrations of inflammatory markers and endothelial dysfunction, thus suggesting a mechanism for the role of these patterns in the development of atherosclerosis.

We showed that in the rats, fed the hypercholesterolaemic diet for 12 weeks, that induced a 10-fold increase in LDL levels in blood, endotheliumdependent vascular function was not affected. Indeed, there was no impairment of NO-dependent vascular function as evidence by 1 . unchanged magnitude of acetylcholine-induced vascular relaxation responses and 2. no significant effect of L-NAME (an inhibitor of NO synthesis) on these responses. Hence, our data 
strongly suggest that pronounced and prolonged hypercholesterolaemia in rats does not lead to endothelial dysfunction. Moreover, hypercholesterolaemiainduced inflammatory response was rather weak as measured by IL-6 in blood. IL-6 increased to maximum of $75 \%$ (week 8; the high-cholesterol diet). However, after 4 or 12 weeks on the hypercholesterolaemic diet, IL-6 levels did not increase by more than $35 \%$ of the control value.

Slightly elevated plasma concentrations of IL-6 may be considered to be a marker of an inflammatory state. This effect could have resulted from the endothelial response mediated by monocyte-derived macrophages and $\mathrm{T}$ lymphocytes, in early stages of atherosclerosis (Ross, 1999). Therefore, the above findings might suggest that diet-induced hypercholesterolaemia led to arterial wall inflammatory response of mild degree. In the same way, mild hyperhomocysteinaemia induced early atherosclerotic inflammatory process of the vascular endothelium in Sprague-Dawley rats (Zhang et al., 2004). However, such a mild arterial inflammatory response was not associated with inflammatory liver response. Indeed CRP levels in rats were below detection limit throughout the whole period of 12 weeks of feeding the hypercholesterolaemic diet. Accordingly, even though hipercholesterolaemia in rats may activate local vascular inflammatory response to a minor degree (increased IL-6 production) it does not lead to significant systemic inflammatory response in the liver i.e. production of CRP (Blake and Ridker, 2001; Libby et al., 2002).

\section{CONCLUSIONS}

In conlusion, diet containing cholesterol in rats does not lead to atherosclerotic plaque development since it does not affect endothelial function and does not induce systemic inflammatory responses; both seem to be mandatory for atherosclerosis to develop. These findings may possibly invalidate the use of laboratory normotensive Wistar rats as models for development of hypercholesterolaemiadependent atherosclerosis.

\section{REFERENCES}

Bagger M., Andersen O., Nielsen J.B., Ryttig K.R., 1996. Dietary fibres reduce blood pressure, serum total cholesterol and platelet aggregation in rats. Brit. J. Nutr. 75, 483-493

Blake G.J., Ridker P.M., 2001. Novel clinical markers of vascular wall inflammation. Circ. Res. 89, 763-771

Bonetti P.O., Lerman L.O., Lerman A., 2003. Endothelial dysfunction: a marker of atherosclerotic risk. Arterioscler. Thromb. Vasc. Biol. 23, 168-175 
Chango A., Villaume Ch., Bau H.M., Schwerz A., Nicolas J.P., Mejan L., 1998. Effects of casein, sweet white lupin and sweet yellow lupin diet on cholesterol metabolism in rats. J. Sci. Food Agr. 76, 303-309

Day C.E., Phillips W.A., Schurr P.E., 1979. Animal models for an integrated approach to the pharmacologic control of atherosclerosis. Artery 5, 90-96

Friedewald W.T., Levy R.I., Fredrickson D.S., 1972. Estimation of the concentration of low-density lipoprotein cholesterol in plasma, without use of the preparative centrifuge. Clin. Chem. 18, 499-502

Friedrich M., Piech M., 2000. Effects of diet enrichment with naked oats on blood glucose and lipid species and on the weight growth and accumulation of pericardial and peri-intestinal adipose tissue in rats. Pol. J. Food Nutr. Sci. 50, 61-65

German J.B., Bauman D.E., Burrin D.G., Failla M.L., Freake H.C., King J.C., Klein S., Milner J.A., Pelto G.H., Rasmussen K.M., Zeisel S.H., 2004. Metabolomics in the opening decade of the 21st century: building the roads to individualized health. J. Nutr. 134, 2729-2732

Hecker K.D., Meier M.L., Newman R.K., Newman C.W., 1998. Barley $\beta$-glucan is effective as a hypocholesterolaemic ingredient in foods. J. Sci. Food Agr. 77, 179-183

Lamb D.J., El-Sankary W., Ferns G.A.A., 2002. Molecular mimicry in atherosclerosis: a role for heat shock proteins in immunisation. Atherosclerosis 167, 177-185

Libby P., 2000. Changing concepts of atherogenesis. J. Intern. Med. 247, 349-358

Libby P., Ridker P.M., Maseri A., 2002. Inflammation and atherosclerosis. Circulation 105, 1135-1143

Lopez-Garcia E., Schulze M.B., Fung T.T., Meigs J.B., Rifai N., Manson J.E., Hu F.B., 2004. Major dietary patterns are related to plasma concentrations of markers of inflammation and endothelial disfunction. Amer. J. Clin. Nutr. 80, 1029-1035

Lusis A.J., 2000. Atherosclerosis. Nature 407, 233-241

Madani S., Lopez S., Blond J.P., Prost J., Belleville J., 1998. Highly purified soybean protein is not hypercholesterolemic in rats but stimulates cholesterol synthesis and excretion and reduces polyunsaturated fatty acid biosynthesis. J. Nutr. 128, 1084-1091

Macarulla M.T., Medina C., De Diego M.A., Chávarri M., Zulet M.Á., Martínez J.A., NöelSuberville C., Higueret P., Portillo M.P., 2001. Effects of whole seed and a protein isolate of faba bean (Vicia faba) on the cholesterol metabolism in hypercholsterolaemic rats. Brit. J. Nutr. $85,607-614$

Mangiapane E.H., Salter A.M., 1999. Diet, Lipoproteins and Coronary Heart Disease. Nottingham, Nottingham University Press

McAteer M.A., Gruimsditch D.C., Vidgeon-Hart M., Benson G.M., Salter A.W., 2003. Dietary cholesterol reduces lipoprotein lipase activity in the atherosclerosis-susceptible Bio $\mathrm{F}_{1} \mathrm{~B}$ hamster. Brit. J. Nutr. 89, 341-350

Moghadasian M.H., 2002. Experimental atherosclerosis: a historical overview. Life Sci. 70, 855-865

Morita T., Oh-Hashi A., Takei K., Ikai M., Kasaoka S., Kiriyama S., 1997. Cholesterol-lowering effects of soybean, potato and rice proteins depend on their low methionine content in rats fed a cholesterol-free purified diet. J. Nutr. 127, 470-477

Ntianos F.Y., van de Kooij A.J., de Deckere E.A.M., Duchateau G.S.M.J.E., Trautwein E.A., 2003. Effects of various amounts of dietary plant sterol esters on plasma and hepatic sterol concentration and aortic foam cell formation of cholesterol-fed hamsters. Atherosclerosis 169, 41-50

Pasceri V., Willerson J.T., Yeh E.T., 2000. Direct proinflammatory effect of C-reactive protein on human endothelial cells. Circulation 102, 2165-2168

Pisulewski P.M., Kopeć A., Cieślik E., 2002. A note on the development of a rat model for cholesterol and lipoprotein metabolism. Pol. J. Food Nutr. Sci. 52, 63-66

Reeves P.G., Nielsen F.H., Fahey G., 1993. AIN-93 Purified diets for laboratory rodents: final report of the Amrican Institute of Nutrition ad hoc writing committee on the reformulation of the AIN76 rodent diet. J. Nutr. 123, 1939-1951 
Ridker P.M., Hennekens C.H., Buring J.E., Rifai N., 2000. C-reactive protein and other markers of inflammation in the prediction of cardiovascular disease in women. N. Engl. J. Med. 342, 836-843

Ross R., 1999. Atherosclerosis-an inflammatory disease. N. Engl. J. Med. 340, 115-126

Stehbens W.E., 2001a. Coronary heart disease, hypercholesterolemia and atherosclerosis. I. False premises. Exp. Mol. Pathol. 70, 103-119

Stehbens W.E., 2001b. Coronary heart disease, hypercholesterolemia and atherosclerosis. II. Misrepresented data. Exp. Mol. Pathol. 70, 120-139

Suk H.J., Ridker P.M., Cook N.R., Zee R.Y.L., 2005. Relation of polymorphism within the Creactive protein gene and plasma CRP levels. Atherosclerosis 178, 139-145

Troszyńska A., Bałasińska B., 2002. Antioxidant activity of crude tannins of pea (Pisum sativum) seed coat and their hypocholesterolemic effects in rats. Pol. J. Food Nutr. Sci. 52, 33-38

Vasconen T., Mervaala E., Krogerus L., Karppanen H., 2002. Suplementation of plant sterols and minerals benefits obese Zucker rats fed an atherogenic diet. J. Nutr. 132, 231-237

Wołoch R., Pisulewski P.M., 2003. Effect of flour derived from naked and covered forms of barley and oat on serum lipid profile in rats (in Polish). Biul. IHAR 229, 271-281

Zhang R., Ma J., Xia M., Zhu H., Ling W.H., 2004. Mild hypercholesterolemia induced by feeding rats diets rich in methionine or deficient in folate promotes early atherosclerotic inflammatory process. J. Nutr. 134, 825-830

\section{STRESZCZENIE}

\section{Krytyczna ocena szczurów normotensywnych jako modelu w badaniach nad wpływem hipercholesterolemii na rozwój miażdżycy}

W świetle współczesnych poglądów miażdżyca jest chorobą rozwijającą się na tle stanu zapalnego śródbłonka naczyń krwionośnych. Celem pracy była krytyczna ocena przydatności normotensywnych szczurów laboratoryjnych (szczepu Wistar) jako modelu w badaniach nad wpływem żywieniowo indukowanej hipercholesterolemii na rozwój miażdżycy. Szczury, 5-tygodniowe samce szczepu Wistar $(n=40)$, rozlosowano do dwóch równoliczebnych grup, żywionych przez 12 tygodni dwiema różnymi dietami: 1 - dieta kontrolna (AIN-93G) i 2 - hipercholesterolemiczna dieta AIN-93G (cholesterol, $1 \mathrm{~g} / 100 \mathrm{~g}$; kwas cholowy, 0,5 g/100 g). W próbkach krwi oznaczano profil lipidowy oraz wskaźniki stanu zapalnego po $0,4,8$ i 12 tygodniach. Jednocześnie badano funkcje czynnościowe śródbłonka aorty. Oceniono histologiczne zmiany miażdżycowe w aortach szczurów po 12 tygodniach. W przeciwieństwie do zwierząt $\mathrm{z}$ grupy 1 (kontrolnej), u szczurów żywionych dietą 2 (hipercholesterolemiczną) stwierdzono podwyższony poziom cholestetrolu całkowitego ( $2,05 \mathrm{vs} 7,97 \mathrm{mmol} / \mathrm{L}) \mathrm{i}$ cholesterolu frakcji LDL (0,63 vs $6,80 \mathrm{mmol} / \mathrm{L})$. Cholesterol frakcji HDL był nieznacznie obniżony, a poziom tracylgliceroli nie uległ zmianie. Szczury żywione dietą hipercholesterolemiczną wykazywały stosunkowo niewielki wzrost poziomu prozapalnej interleukiny $6(2,6 \mathrm{vs} \mathrm{4,85} \mathrm{pg} / \mathrm{ml})$, a poziom prozapalnego białka C-reaktywnego nie przekraczał granic wykrywalności $(<0,01 \mathrm{pg} / \mathrm{ml})$. Krzywe relaksacyjnej odpowiedzi śródbłonka aort na acetylocholinę (test na śródbłonkowozależny rozkurcz naczyń) nie ulegały upośledzeniu u szczurów żywionych dietą hipercholesterolemiczną. Podobnie, dieta ta nie wywoływała zmian miażdżycowych w aortach szczurów.

W podsumowaniu, hipercholesterolemia uzyskana na drodze żywieniowej wywołuje jedynie ograniczoną reakcję zapalną i nie prowadzi do upośledzenia funkcji śródbłonka naczyń, ani też do rozwoju zmian miażdżycowych u szczurów normotensywnych. Powyższe obserwacje podważają przydatność tych zwierząt jako modelu w badaniach nad wpływem hipercholesterolemii na rozwój miażdżycy. 